\title{
ATRX Mutation Analysis Testing Method
}

National Cancer Institute

\section{Source}

National Cancer Institute. ATRX Mutation Analysis Testing Method. NCI Thesaurus. Code C158853.

A request to enter the specific molecular analysis method used to detect and identify mutations in the ATRX gene. 